\title{
Queer Hermeneutics: Who is that Queer/n in the Picture? Contemporary Philosophical Hermeneutics $^{1}$
}

\author{
RalPh CARL Wushke
}

Ralph Carl Wushke is a Th.M. graduate (2004) of Toronto School of
Theology, Emmanuel College.

Preface

$\mathrm{W}$

hen I returned to the academy in 2000 one of the goals I stated to myself and others was to reflect on the paths my life has taken. Contemporary philosophical hermeneutics-post-modern philosophy and deconstruction-resting on Schleiermacher's assertion that "the height of understanding is to understand any author better than he understood himself" (72) offers points of access and resources for this journey of (self)understanding. Hermeneutics involves textual exploration and understanding. In this instance the texts for exploration are a black and white photo of two people that is in my possession, and a reproduction of a portion of the same image on a page on the World Wide Web that was online in the fall of $2001 .^{2}$ I intend to connect these images with some additional texts I have written in the years, bracketed by the appearance of the first image and its online version, with a view to

I This paper was presented at a joint session of the Canadian Lesbian and Gay Studies Association and the Canadian Society of Biblical Studies, June 1, 2004, Winnipeg.

$2<$ http://www.quadrat.com/party/>. No longer online. 


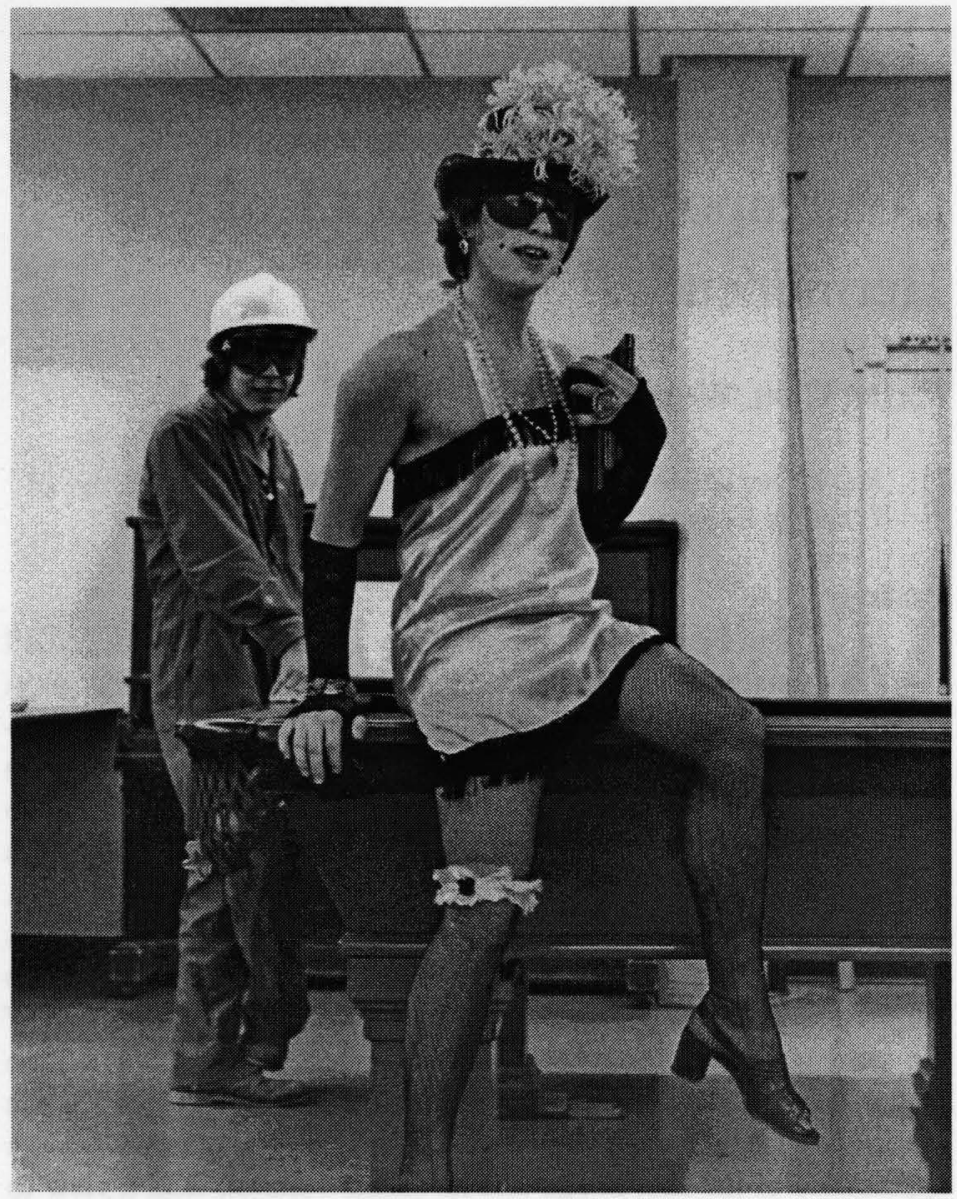

exploring what was / is (un)said in all these texts. I would like to reflect on this hermeneutical exercise in light of a close reading of the "hermeneutic spiral" proposed by James Olthuis (2000), with reference to selected texts of Jacques Derrida, John Caputo and Paul Ricoeur.

I realize the risk in doing this is that $\mathrm{I}$ am (re)counting and perhaps (re)creating memories. Is this truth or fiction? The (im)possibility of perfectly truthful (re)telling brings a quote from Jacques Derrida (2000) to mind: 
Funerary speech and writing would not follow upon death; they work on life in what we call autobiography. And this takes place between fiction and truth, Dichtung and Wahrheit.... An obvious allusion to a distinction between fiction and autobiography that not only remains undecidable but, far more serious, in whose indecidability, as de Man makes clear, it is impossible to stand, to maintain oneself in a stable or stationary way. (Derrida 16)

This short paper also rests uneasily in that indecidability, on the shifting boundary between literature and therapeutic exploration, between autobiography and fiction, since much of it is (re)created and (re)membered-and the testimony of memory can be both deceptive and inventive.

\section{(Re)Reading the First Text}

What is actually in the photograph (as seen on page 210)? What is the plain sense of the text? The photograph is an enlargement of an amateur candid shot of a young Caucasian (fe)male. S/he stands in the foreground complete with boa feather headgear, pearl necklace, teardrop earrings, ostentatious ring, fringed shoulderless dress, poorgirl gloves fish-net stockings, sling-back pumps and garter. Is $\mathrm{s} / \mathrm{he}$ a cancan ${ }^{3}$ girl or a flapper? ${ }^{4}$ Either way s/he is toying with the risqué or has a rebellious side. S/he appears to be looking off into the distance in mid-sentence. $\mathrm{S} / \mathrm{he}$ is masked. $\mathrm{S} / \mathrm{he}$ is supporting herself on the ledge of a billiard table, and is clutching something that looks like a collection of books.

In the background, a more obviously male Caucasian is giving $\mathrm{him} / \mathrm{her}$ the gaze. He is also masked, and wearing a basic construction worker outfit with hardhat, overalls and work boots. $\mathrm{He}$ is a stereotype of masculinity (and heteronormativity?). Does he symbolize the myth of stable gender categories operative in the room? Further in the background, a piano, pool cue stand and pool cue rest. The room is nondescript and does not do the flapper/ cancan girl justice.

${ }^{3}$ cancan: a woman's dance of French origin characterized by high kicking usu. while holding up the front of a full ruffled skirt. Webster's Third International Dictionary, 1981.

${ }^{4}$ flapper $\mathrm{c}$ : a young woman who aggressively manifests freedom from constraint and convention in conduct and dress-used esp. during the period of World War I and the following decade. Webster's Third International Dictionary, 1981. 


\section{2 / Wushke}

All of this is circumscribed by a cheap plastic frame.

What is outside the frame? What (con)text impinges on the text? It's Hallowe'en, Friday, Ocober 31,1975 . The venue is the recreation room at the Lutheran Theological Seminary in Saskatoon. The other party-goers are seminarians, their friends, seminary professors and spouses, the "seminary community."

\section{A Second Look}

What was being said at the event, the moment in time that is captured by the picture? In Foucauldian terms, performing drag is a discursive activity, a statement in a larger discursive formation. ${ }^{5}$ It references other occasions of drag and signals play with gender and sexual orientation. Playing with gender, dressing up in this cancan get-up, was a way of risking disclosure. This event captured in the photograph points to a secret that does (not) want to be told. The image evokes Caputo's exploration of the (non)secret in Derrida: "the secret is constituted by saying and thinking it as a secret, so that it is both divulged and negated" (Caputo 33). This image validates Caputo's observation that "[i]f it were utterly secret, if the secret were purely secret, there would be no secret to keep safe. A pure secret, like a pure gift, makes no appearance and has no phenomenality. 'There is no secret as such; I deny it"' (33).

Likewise the photograph has the potential to play with the Derridean themes of deconstruction and différance. As Caputo says: "Deconstruction is rather the thought of an absolute heterogeneity that unsettles all the assurance of the same within which we comfortably ensconce ourselves. That is the desire by which it is moved, which moves and impassions it, which sets it into motion, toward which it extends itself" (5). He continues, "[d]ifférance supplies a condition under which something is constituted or constructible and at the same time through and through deconstructible" (12). The photograph, and the moment it captures, seem to be crying out for deconstruction, and différance makes that possible; it opens up the moment and allows multiple viewpoints of the photograph.

5 "Statement" and "discursive formation" are concepts elaborately formulated by Michel Foucault. See The Archaeology of Knowledge (1969). 
The photograph was taken a year before I came out, an event that would not take place until October 19, 1976, the first time I voiced "the secret." Nevertheless something was being said that night. As I (de)constructed my own gender, was I hoping that my secret would be less of a secret? Perhaps. Was I (not) saying to my professors (most of whom were in attendance) and my classmates, "I am the homosexual in your midst"? Perhaps.

The photo captures a moment of a secret, which in Derridean terms is not a true secret. The only reason there could be a secret was because it was known to me already, and perhaps suspected by others. I knew the secret and wanted others to know it as well. The dominant preoccupation of the next few years of my life would be that (non)secret. In deconstruction, neither the (con)text nor the text are stable. The 1975 text in that context did (not) say certain things. The 2001 version of the text says different things. I would like to use (re)created dialogues to explore the (non)secrets in these two texts.

\section{Voices at the Hallowe'en Party}

Seminarian: "Can I really do this? No one knows I'm a homosexual. Maybe they do know already. Do I (not) want them to know?"

Seminarian: "I wonder if they're suspecting I'm homosexual. Maybe I shouldn't have done this. The professors look amused. That's a relief."

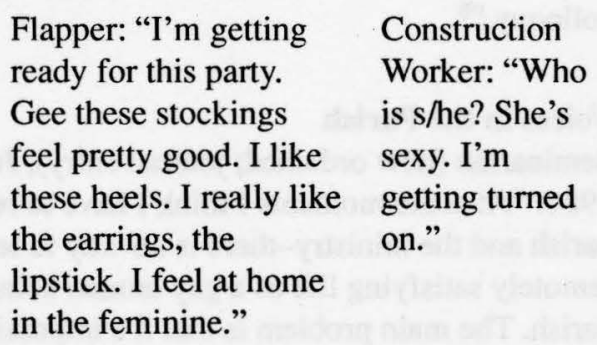

Crowd: "Is that really Ralph???" "He is amazing as a woman!"
Flapper: "I wish I could tell them what's really going on here tonight."
Some silent voices: "I always thought he was gay." 


\section{Voices from Internship}

Seminarian (diary entry) Flapper: "I wonder Crowd: "What's Oct. 19, 1976: "This is the if this means my he so happy greatest day-the fifteen work is done now." about? Why can't year Advent has ended." he tell us?"

Seminarian: (to professor) Flapper: "Oh God, Professor: "I "The reason I'm unsure here we go again." about ordination is because I'm homosexual. Can I be a pastor in this church?"

Seminarian: (to seminary president) "I'm homoFlapper: "Wow, that was easier than I thought it sexual, and I am afraid someone is going to raise the question of sexual was going to be." think you will make a fine pastor in our church." orientation during the colloquy."

\section{Voices in the Parish}

Seminarian (now ordained; journal entry), June 12, 1984: "At some moments I think I have to resign this parish and the ministry-there is no way to lead a remotely satisfying life as a gay human being in the parish. The main problem is that it's impossible to be completely open and share oneself in the modeling of the kind of trust that will create community."

Seminarian, October 4, 1984 (in a letter to his friends and family): "In my personal and spiritual Others: "Is odyssey I have returned to the centre and am moving he going to out again... At this point in my life I must leave my present parish and pastoral office... In order to live and act on the gospel I must take the risk to leave

Seminary President: "If anyone does, I'll tell them it's none of their business." come out?" 
this work and the security and identity which I derive from it. It might be called 'taking up one's cross...' for, for me at least, it includes a certain element of risk."

Seminarian, February 23, 1989 (letter to immediate and extended family): "[M]uch effort in my life is being expended toward justice for gays and lesbians in church and society... At this point I have reached the delightful stage of self-acceptance and recognize that my sexuality, while perhaps in the numerical minority is a gift of God and therefore something to be thankful for, and not hidden."

Family: "We cried when we read your letter. We are so proud of you." Other family members: Silence.

\section{Voices Toronto/Saskatchewan}

Seminarian (in an article for inclusion in the 75th Anniversary book of the Lutheran parish in

Prairie Redvers, Saskatchewan), December 10, 1997: “In reflecting on what I wrote in the first edition of the Dannevirke history book [in 1983], it is clear that biography omits much: the deep anxiety and longings of which I dared not speak or write for fear. The things which fear would not let me put in public were nevertheless being written in the privacy of my journal, spoken of in safe conversations and prayed about in innumerable moments of soul-searching conversation with the Creator."

"When I resigned from the pastorate of Dannevirke Lutheran Church in fall, 1984, I did so because I wanted to take leave of the parish in a way that was not disruptive, so that I could move away from that particular place, both physically and psychologically, to "come out' in the broader context of church and society."

Voices:

"Are you sure you want this article published in our history book?"

Prairie

Voices:

"We don't want that in our history book!"

\section{Reading the Second Text}

The second text, a page from the World Wide Web, (re)produces a portion of the first, the image of the flapper, this time surrounded by 
marquee lights, overlaid with the caption "Silver Anniversary of a Queer/n" in elegant script. "Queer/n" is highlighted with a radiant pink and gold sunburst. Beneath the caption the announcement for a party follows:

Where: 11 Givins Street, Toronto

When: Friday, October 19, 2001 (25 years to the day since little Ralphie first came out of the closet!)

Time: after 8:00 pm

What to Bring:

- Little something to drink

- Your favourite 70s disco tape or CD

Dress Code: Retro, preferably 70 s, but any decade since the 50 s will do!

RSVP

\section{A Second Look}

An image from a party in 1975 that veiled a (non)secret is (re)used to once more unveil the secret that has been told a thousand times and enjoins to celebration. The reference to a "Silver Anniversary" so common for heterosexual wedding anniversaries is (re)claimed to mark 25 years of a gay life lived ever further out of the closet. Combining "Queer" and "Queen" in the postmodern "Queer/n" (re)claims two terms often used pejoratively of male homosexuals and simultaneously references the Silver Jubilee of a reigning monarch.

\section{Voices 2001}

Flapper and seminarian thinking about the present, Crowd: [Individual voices; no longer a crowd to be feared.] past and future:

"Yes, that's me. Queer as a [Inscription on the back of a three dollar bill, and proud of it. You didn't recognize me? It's been a roller coaster ride but I wouldn't change a thing!" framed mixed media painting on mylar of a naked male torso] "To Ralph, in celebration of twentyfive years of being who you are." 
"How many times had I practiced those words and sentences to myself: 'I am a homosexual' before actually managing to say them to another human being?"

"Mom and Dad, there's something I'd like to talk to you about ... and when two men love each other the way a man and woman often do, that's homosexuality. I am homosexual."

"My partner and I own our home, walk without shame down our street, and create moments of family around our dinner table."

"My Christmas card list is a great treasure - the men I have loved and still care for deeply."

"I love my homosexual, gay, queer body self and the lives I live in/with it: pastor and student, AIDS activist and theologian, singer and lover, Lutheran and United, cook and gardener, son and uncle, citizen and neighbour."
"Since 1976 your 'closet' is partially empty, for it still miss (sic) you.

Happy 25th Anniversary!"

“... I too celebrate your 25 th anniversary. You have and still are (sic) a courageous trail blazer on many levels. You embrace perseverance for yourself, which gives hope to many who need it. You are just a wonderful queer guy!"

RALPH, RALPH, MODEL ELF*

For twenty-five years Ralph's been out.

That closet, too tiny, no doubt, Just could not contain him, And no one could chain him.

He had to be out and about.

The church he has made quite uneasy. In fact, there are some who are queasy. They close all the doors, Averting all wars -

A challenge that hasn't been easy.

For us, Ralph has been an example.

His influence surely is ample.

If all were like him, Hope wouldn't be dim.

His bravery we should all sample.

*elf - a tiny, often mischievous fairy ${ }^{7}$

${ }^{7}$ Brian G. Rude, email correspondence with the author, Jan. 10, 2002. 


\section{Hermeneutical / Therapeutic Reflections}

In his essay, "The Model of the Text: Meaningful Action Considered as Text," Paul Ricoeur suggests that human actions and events may leave "marks" on time which may be read for understanding, "Verstehen" (529). He says, "[a]n important action, we could say develops meanings which can be actualized or fulfilled in situations other than the one in which this action occurred" (543). He adds, "like a text, human action is an open work, the meaning of which is "in suspense"" (544). In light of Ricoeur I would suggest that the events referenced by the two texts at hand, a party in 1975 and another one in 2001, are events which can be read through these "marks," a photograph and a page from the World Wide Web. Others could read these texts, but for the purpose of this essay, it is I who will read them with verstehen as my purpose.

James H. Olthuis, in "Otherwise than Violence: Toward a Hermeneutics of Connection" (2000), casts an illuminating (spot?)light on this hermeneutic exercise. Olthuis suggests that the hermeneutic task is one of journeying with the "other" and that the other may be "persons, texts, artworks, or even animals or trees as well as God" (137) - categories broad enough to include the two "texts" considered above. The fourfold "hermeneutic spiral of connection" (148) Olthuis describes has many applications, including the meeting of the "other" in a therapeutic relationship. This is significant here because the exercise at hand is both a hermeneutic and a therapeutic one. The person depicted in the texts and I are (not) the same person. I am indulging in the risky exercise of (re)discovery in images of myself as "other," someone I once was, and both am and am not today. Olthuis' hermeneutic model offers some traces within which to explore, without precluding side trips (see his concept of "meandering") (153). For me this is an exercise in therapeutic hermeneutics because I believe I have not taken enough time to "know myself." At the same time it places me in the odd position of carrying out a hermeneutical exercise on something very close to myself.

Encountering the "other" can precipitate threat or invite "mutual recognition, mutual pleasure, and mutual empowerment" (140). The first text under consideration holds both these possibilities for me. The photograph of the flapper / cancan girl long held fear and fascination for me. I stored it in a file cabinet drawer alongside decades-old essays, not wanting it seen, but at the same time not 
willing to discard or destroy it. From time to time I would come across it unawares, and be surprised or shocked, intrigued or ashamed. As Olthuis says, "When something very strange shows itself, when differences of time, location and kind multiply, interpretation becomes problematic and calls for special attention" (140-1).

By (re)visiting the first image, and its later iteration I (re)discover "the internal psychic space[s], the interstice[s] between signs and referents, the distances between self and others, ... the birthplace[s] of hermeneutics" (Olthuis 142). In this space between these images and myself I do want to hear Derrida's "pre-originary "yes"' (in Olthuis 144), which Olthuis, with reference to Julia Kristeva, describes as "[l]ove (as both the energy of connection and the yearning for connection with self, others, creation and God)" (144, emphasis added).

Olthuis' four-stage description of this process as a "two-way hermeneutic dance" (145) is a happy choice for this autobiographical exercise. Both flappers and cancan girls were dancers, dancers who pushed the boundaries of sexuality and the decorum of the body in their societies. As expressions of my closeted self, I do believe they have always wanted to dance! At the same time the notion of mutuality implied in the two-way dance that "lets the other be the other, and simultaneously, lets oneself be open to the other" (146) may just be more possible when the person depicted in the texts and the author have identical genetic makeup, and have had over-lapping life spans. I want to respect and know that flapper very deeply, and I want to be known by him/her. In this exercise there is a strong bias toward knowing each other's heart $\grave{a}$ la Levinas (in Olthuis 146).

\section{Postscript}

In his later book, The Beautiful Risk, Jim Olthuis (2001) describes the healing process as a spiral. "Half the time we move backward in order to find a way forward" (161). This exercise has felt very much like that. My life à-venir as pastor / student / lover / friend is (un)assured but hopeful. The wrestling with Little Ralphie and the rebellious Flapper will doubtless be (re)visited, but perhaps a little more skillfully.

In a 1989 interview, published in Acts of Literature (1992), Derrida reflects on his own approach to literature and autobiography: 
And deep down this is still my most naïve desire. I don't dream of either a literary work, or a philosophical work, but that everything that occurs, happens to me or fails to, should be as it were sealed (placed in reserve, hidden so as to be kept ...) ... This desire for everything $+n-$ naturally I can analyze it, "deconstruct" it, criticize it, but it is an experience I love, that I know and recognize" (35).

In the same interview Derrida talks about "a singular mark," also "repeatable, iterable, as mark" (43), which "then begins to differ from itself sufficiently to become exemplary and thus involve a certain generality" (43).

As I think about the (re)stor(y)ing-within the hermeneutic / therapeutic spiral-Derrida's notion of the generality of the singular mark comes into play. How many more (con)texts might I (re)read to explore the creative in-between places, Olthuis' "wild spaces of love" (142)? Are there others who on hearing / reading this text might find echoes and applications in their own journey to risk selfacceptance and the rejection or acceptance of those around them? This autobiographical hermeneutic practice might in turn be generalizable in non-autobiographical settings, with the "other" whenever and wherever encountered. Can I venture the same risks with the non-autobiographical "other" as I have with these two texts? With Derrida I want to say, Oui, oui. Viens!

\section{Works Cited}

Caputo, John D. The Prayers and Tears of Jacques Derrida: Religion without Religion. Indianapolis: Indiana University Press, 1997. Derrida, Jacques. "An Interview with Jacques Derrida." Ed. Derek Attridge. Acts of Literature. New York: Routledge, 1992.

- Demeure: Fiction and Testimony. Trans. Elizabeth Rottenberg. Stanford, California: Stanford University Press, 2000.

Foucault, Michel. The Archaeology of Knowledge. 1969. London: Routledge, 2002.

Klemm, David E. Hermeneutical Inquiry, Volume I: The Interpretation of Texts. Atlanta: Scholars Press, 1896.

Olthuis, James H. The Beautiful Risk: A New Psychology of Loving and Being Loved. Grand Rapids: Zondervan, 2001. 
- "Otherwise Than Violence: Towards a Hermeneutic of Connection." The Arts, Community and Cultural Democracy. Eds. Lambert Zuidervaart and Henry Luitzikhuisen. London: Macmillan Press Ltd., 2000: 137-64.

Ricoeur, Paul. Interpretation Theory. Fort Worth: Texas Christian University Press, 1976.

Schleiermacher, Friedrich. "The Academy Addresses of 1829: On the Concept of Hermeneutics, with reference to F. A. Wolf's Instructions and Ast's Textbook." Rpt. in Hermeneutical Inquiry, Volume I: The Interpretation of Texts. Ed. David E. Klemm. Atlanta: Scholars Press, 1986. 